\title{
Carcinoid tumour presenting as recurrent pneumonia
}

\author{
Ruvini Dharmagunawardena, ${ }^{1}$ Marc Lipman, ${ }^{1}$ Joanne Cleverley, ${ }^{2}$ Charlotte Cash $^{2}$
}

1 Department of Thoracic Medicine, Royal Free Hospital, London, UK

${ }^{2}$ Department of Radiology, Royal Free Hospital, London, UK

\section{Correspondence to} Dr Ruvini

Dharmagunawardena, ruvini.dharmagunawardena@ nhs.net

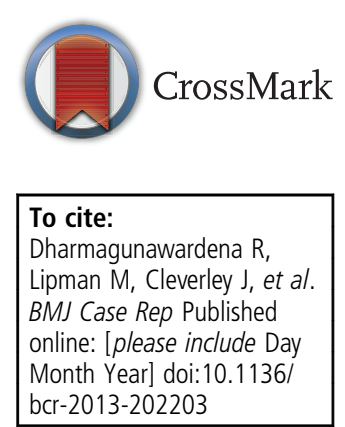

\section{DESCRIPTION}

A 39-year-old woman non-smoker gave a history of three separate episodes of pneumonia over 2 years. Each involved the right lower lobe (figure 1), and clinical plus chest radiographic resolution was achieved following antibiotics. CT of the chest revealed a partially calcified lesion lying externally adjacent to the right lower lobe bronchus causing partial compression of the lumen (figure 2A,

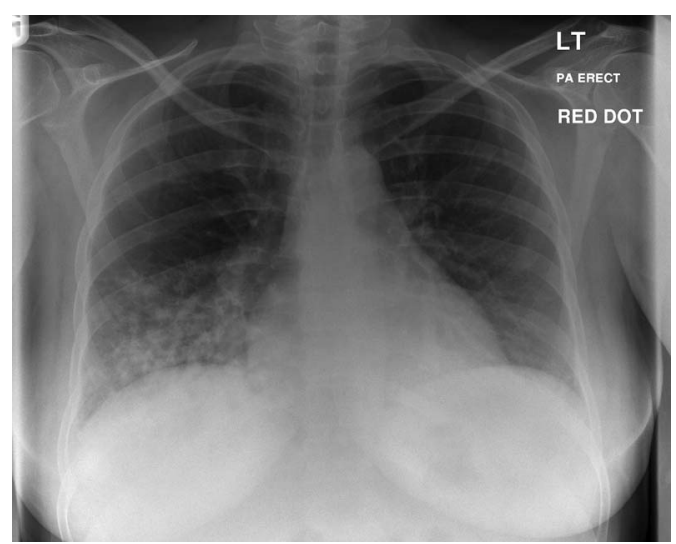

Figure 1 Chest radiograph showing right lower lobe consolidation.
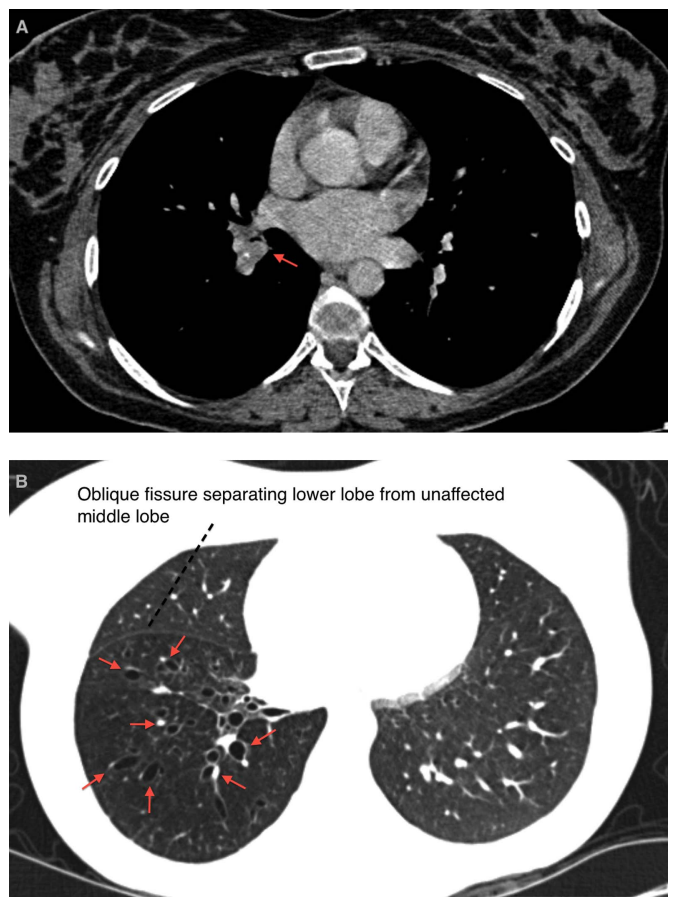

Figure 2 (A) CT scan showing a partially calcified lesion causing obstruction to the lumen of the right lower lobe bronchus. (B) CT scan showing distal bronchiectasis. arrow) with distal bronchiectasis confined to the right lower lobe (figure 2B, arrows). Positron emission tomography scan showed no other lesions.

Rigid bronchoscopy demonstrated a vascular mass in the lower lobe orifice adjacent to the middle lobe. A right lower lobectomy was performed. Histology confirmed a $1.4 \times 1 \times 1 \mathrm{~cm} \mathrm{car}-$ cinoid tumour with clear resection margins and no lymph node involvement. She made a full recovery.

\section{Learning points}

- Pneumonia recurring at a fixed location should prompt exclusion of anatomical abnormalities including congenital malformations, obstructing lesions and bronchiectasis.

- Here, bronchiectasis arose secondary to a slow-growing, curable tumour.

- Carcinoid tumours are rare (1-2\% of all lung tumours), ${ }^{1}$ and the majority of symptoms arise from direct involvement of the bronchopulmonary tree. ${ }^{2}$

Contributors $\mathrm{RD}$ and $\mathrm{ML}$ were involved in the drafting, selection of images and revision of the manuscript. JC and CC were involved in the interpretation and selection of the imaging studies. All authors have agreed on the final version. RD is the guarantor of the content.

Competing interests None.

Patient consent Obtained.

Provenance and peer review Not commissioned; externally peer reviewed.

\section{REFERENCES}

1 Harpole DH Jr, Feldman JM, Buchanan S, et al. Bronchial carcinoid tumours: a retrospective analysis of 126 patients. Ann Thorac Surg 1992; $54: 50-5$

2 Hage $R$, de la Rivière $A B$, Seldenrijk $C A$, et al. Update in pulmonary carcinoid tumors: a review article. Ann Surg Oncol 2003; 10:697-704. 
Copyright 2013 BMJ Publishing Group. All rights reserved. For permission to reuse any of this content visit http://group.bmj.com/group/rights-licensing/permissions.

BMJ Case Report Fellows may re-use this article for personal use and teaching without any further permission.

Become a Fellow of BMJ Case Reports today and you can:

- Submit as many cases as you like

- Enjoy fast sympathetic peer review and rapid publication of accepted articles

- Access all the published articles

- Re-use any of the published material for personal use and teaching without further permission

For information on Institutional Fellowships contact consortiasales@bmjgroup.com

Visit casereports.bmj.com for more articles like this and to become a Fellow 